\title{
GENETIC PROFILES AND DIVERSITY OF BALTIC SPRING BARLEY MATERIAL
}

\author{
Agnese Kolodinska Brantestam*,**, Isaak Rashal*, Stine Tuvesson***, Jens Weibull ${ }^{\star * * *}$ \\ and Roland von Bothmer **, ***** \\ * Institute of Biology, University of Latvia, Miera iela 3, Salaspils LV-2169, LATVIA \\ agnese.kolodinska@nordgen.org \\ ** Nordic Genetic Resource Center, Smedjevägen 3, Alnarp SE-23053, SWEDEN \\ *** Lantmännen SW Seed, Onnsjögatan 13, Svalöv SE-26881, SWEDEN \\ **** Swedish Board of Agriculture, Vallgatan 8, Jönköping SE-55182, SWEDEN \\ ***** Swedish University of Agricultural Sciences, Sundsvägen 10, Alnarp SE-23053, SWEDEN
}

Contributed by Isaak Rashal

\begin{abstract}
The objectives of this study were to generate molecular passport data for identification and differentiation of Baltic spring barley accessions (cultivars, landraces and breeding lines) and to estimate the genetic variation within and among these accessions. Allelic profiles of 21 microsatellite and 8 isoenzyme loci were obtained and analysed for 64 Baltic spring barley accessions. The microsatellite data was successfully used to separate all of the accessions by individual allelic pattern and frequencies, whereas only 30 of the studied accessions could be distinguished by isozyme data. Variation was detected both among and within the accessions and was significant. The variation within accessions accounted for $20.6 \%$ and $14.3 \%$ of the total variation, based on microsatellite and isozyme data, respectively. The six-rowed and two-rowed material was well differentiated by both types of marker data: according to AMOVA this differentiation accounted for $16.9 \%$ of the microsatellite variation and $26.8 \%$ of isozyme variation. Differentiation of accessions based on the country of origin could be detected only by isozyme markers and accounted for $9 \%$ of the total izozyme variation. Both isozyme and microsatellite data showed that accessions of Latvian origin had the highest total diversity values, while material from Estonia was the least diverse.
\end{abstract}

Key words: barley, Baltic region, izoenzymes, microsatellites, molecular variation.

\section{INTRODUCTION}

Barley is one of the most important crops in the Baltic countries; the area planted annually is about $10 \%$ of the total crop area in Latvia and Lithuania, and 20\% in Estonia (Anonymous, 2012). Professional breeding of this crop was initiated here about 90 years ago and significant improvements of agronomic performance of the crop have been achieved, e.g. yields of spring barley have more than doubled during the last century (http://www.stat.ee; http://www.zm.gov.lv; http://wwwstd.lt). Initially, the cultivars were selected from local and foreign landraces, and in the 1930s, this approach was replaced by combination breeding (Gaike, 1992). The pedigrees of modern cultivars have become complex, and introduction of exotic sources, e.g. sources of disease resistance genes, by number of backcrossing cycles, leads to more adapted materials. Therefore, it is presently difficult to classify material based on a genealogical approach only and molecular methods have become a useful tool to identify and classify breeding material and to estimate genetic variation. The objectives of this study were to determine the genetic relationships and diversity of Estonian, Latvian and Lithuanian spring barley and to generate genetic profiles of the gene bank accessions and breeding material. The accessions discussed in this paper were also included in a larger study together with accessions from Sweden, Denmark, Finland and Norway to study genetic erosion in barley over the last century (Kolodinska Brantestam, 2005). The present paper, however, is focused on the Baltic material only, and assesses genetic diversity, its distribution and relatedness among Baltic spring barley.

\section{MATERIALS AND METHODS}

Materials. The material studied consisted of 64 accessions of spring barley from Estonia, Latvia and Lithuania and included landraces, cultivars and breeding lines (Table 1). Material was obtained from gene banks in the Baltic countries (Commission on Plant Genetic Resources for Food and Agriculture in Estonia; Genetic Resource Centre in Latvia and Plant Gene Bank in Lithuania) and plant breeding 
BARLEY ACCESSIONS, THEIR ORIGIN, TYPE AND YEAR OF RELEASE

\begin{tabular}{|c|c|c|c|c|c|c|c|}
\hline Accession name & $\begin{array}{c}\text { Gene bank } \\
\text { number }\end{array}$ & $\begin{array}{l}\text { Origin } \\
\text { country }\end{array}$ & $\begin{array}{l}\text { Year of } \\
\text { release }\end{array}$ & Accession type & Pedigree & Spike type & Breeding Inst. \\
\hline 1 & 2 & 3 & 4 & 5 & 6 & 7 & 8 \\
\hline 'Latvijas vietēje' & LVA00018 & Latvia & - & landrace & - & two-rowed & - \\
\hline 'Vairogs' & LVA00017 & Latvia & 1930 & cultivar & (S) local material from Priekuḷi & six-rowed & Priekuḷi Br. St. \\
\hline 'Kombainieris' & LVA00009 & Latvia & 1950 & cultivar & 'Maja' x Talsu local material & two-rowed & Stendes Br. St. \\
\hline 'Priekuḷu 1' & LVA00011 & Latvia & 1959 & cultivar & (S) Norwegian local & six-rowed & Priekuḷi Br. St. \\
\hline 'Priekuḷu 60' & LVA00012 & Latvia & 1972 & cultivar & $\begin{array}{l}\text { Talsu local material x 'Maja' x } \\
\text { 'Tammi' }\end{array}$ & two-rowed & Priekuli Br. St. \\
\hline 'Stendes' & LVA00016 & Latvia & 1972 & cultivar & 'Drost' x 'Maja' & two-rowed & Stendes Br. St. \\
\hline 'Abava' & LVA00001 & Latvia & 1978 & cultivar & 'Mari' x 'Elsa' x 'Domen' & two-rowed & Stendes Br. St. \\
\hline 'Ilga' & LVA00006 & Latvia & 1983 & cultivar & $\begin{array}{l}\text { 'KM 1192' x 'Hadmersleben } \\
\text { 70179/70' }\end{array}$ & two-rowed & Priekuli Br. St. \\
\hline 'Agra' & LVA00002 & Latvia & 1984 & cultivar & 'Priekuḷu 1'x 'Otra' & six-rowed & Stendes Br. St. \\
\hline 'Balga' & LVA00004 & Latvia & 1990 & cultivar & 'Gunilla' x 'KM 1192' & two-rowed & Priekuli Br. St. \\
\hline 'Rasa' & LVA00013 & Latvia & 1991 & cultivar & 'France gold' x 'HE-R-54' & two-rowed & Stendes Br. St. \\
\hline 'Klinta' & LVA00008 & Latvia & 1992 & cultivar & 'Torkel' x 'CF-42' & two-rowed & $\begin{array}{l}\text { Agricultural University } \\
\text { of Latvia }\end{array}$ \\
\hline 'Rūja' & LVA00014 & Latvia & 1992 & cultivar & $\begin{array}{l}\text { ('Kombainieris' x 'Triumph') x } \\
\text { 'Abava' }\end{array}$ & two-rowed & Priekuli Br. St. \\
\hline 'Sencis' & LVA00015 & Latvia & 1994 & cultivar & 'Rupal' x 'Ofir' x Torkel & two-rowed & Stendes Br. St. \\
\hline 'Ansis' & LVA00003 & Latvia & 1995 & cultivar & 'KM 246-3-78' x Taifun & two-rowed & Stendes Br. St. \\
\hline 'Gate' & LVA00005 & Latvia & 1995 & cultivar & $\begin{array}{l}\text { 'H 497' x 'Hadmersleben x } \\
\text { 'Nadja'*2 x 'Emir' }\end{array}$ & two-rowed & Priekuli Br. St. \\
\hline 'Malva' & LVA00166 & Latvia & 1998 & cultivar & 'STN8142’ x ‘STN7542’ & two-rowed & $\begin{array}{l}\text { Agricultural University } \\
\text { of Latvia }\end{array}$ \\
\hline 'L-1879' & LVA01393 & Latvia & - & breeding line & unknown & two-rowed & Priekuḷi Br. St. \\
\hline '8154' & - & Latvia & - & breeding line & 'Athos' x 'Ving' & two-rowed & Stendes Br. St. \\
\hline '7978' & - & Latvia & - & breeding line & 'Nadja' x 'Ofir'*2 & two-rowed & Stendes Br. St. \\
\hline '8993' & - & Latvia & - & breeding line & '7233’x 'Belfor' & two-rowed & Stendes Br. St. \\
\hline 'Jogeva' & EST17 & Estonia & 1931 & cultivar & (S) 'Binder' & six-rowed & Jõgeva Pl. Br.Inst. \\
\hline 'Jogeva 1104' & EST18 & Estonia & 1953 & cultivar & 'Maja' x 'Rimpau Hanna & two-rowed & Jõgeva Pl. Br.Inst. \\
\hline 'Toomas' & EST23 & Estonia & 1976 & cultivar & (S) local population & six-rowed & Jõgeva Pl. Br.Inst. \\
\hline 'Liisa' & EST20 & Estonia & 1981 & cultivar & 'Hylkema' x 'Diamant' & two-rowed & Jõgeva Pl. Br.Inst. \\
\hline 'Miina' & EST21 & Estonia & 1981 & cultivar & 'Jogeva' x 'Hylkema' & two-rowed & Jõgeva Pl. Br.Inst. \\
\hline 'Esme' & EST16 & Estonia & 1982 & cultivar & 'Foma' x 'Hylkema' & two-rowed & Jõgeva Pl. Br.Inst. \\
\hline 'Elo' & EST15 & Estonia & 1989 & cultivar & 'Triumph' x 'Lofa' & two-rowed & Jõgeva Pl. Br.Inst. \\
\hline 'Teele' & EST22 & Estonia & 1991 & cultivar & (M) 'Otra' & six-rowed & Jõgeva Pl. Br.Inst. \\
\hline 'Anni' & EST14 & Estonia & 1993 & cultivar & 'Lola' x 'Lisa' & two-rowed & Jõgeva Pl. Br.Inst. \\
\hline 'Leelo' & EST19 & Estonia & 1995 & cultivar & 'Ansgar' x ‘Sv 2552’ x 'Elo’ & two-rowed & Jõgeva Pl. Br.Inst. \\
\hline 'Roosi' & EST240 & Estonia & 1999 & cultivar & ‘Abava' x 'Nadja' x 'Piggi' & two-rowed & Jõgeva Pl. Br.Inst. \\
\hline '2686.10.1.6' & EST575 & Estonia & - & breeding line & ‘1338.3.4’ x ‘Moskva 2' & two-rowed & Jõgeva Pl. Br.Inst. \\
\hline '2734.2.5.5' & EST576 & Estonia & - & breeding line & 'Sv 86298’ x 'Digger' & two-rowed & Jõgeva Pl. Br.Inst. \\
\hline '2867.14.3.3' & - & Estonia & - & breeding line & '546.11.27’ x ‘Ellinor’ & two-rowed & Jõgeva Pl. Br.Inst. \\
\hline '2878.1.6.4' & - & Estonia & - & breeding line & '546.11.27’ x 'KM 1192’ & two-rowed & Jõgeva Pl. Br.Inst. \\
\hline '2928.10.9.9' & - & Estonia & - & breeding line & 'Elo' x 'Ultra' & two-rowed & Jõgeva Pl. Br.Inst. \\
\hline '2951.6.9.3' & - & Estonia & - & breeding line & 'Roland' x 'Defra' & two-rowed & Jõgeva Pl. Br.Inst. \\
\hline '2975.4.1.2' & - & Estonia & - & breeding line & 'Corgi'x 'Ilka' & two-rowed & Jõgeva Pl. Br.Inst. \\
\hline '2987.1.2.1' & - & Estonia & - & breeding line & ‘1338.3.4' x 'Corgi' & two-rowed & Jõgeva Pl. Br.Inst. \\
\hline '3038.3.7.4' & - & Estonia & - & breeding line & '546.11.27’ x ‘Maresi' & two-rowed & Jõgeva Pl. Br.Inst. \\
\hline 'Auksiniai' & AGB00255 & Lithuania & 1927 & cultivar & (S) 'Gul' & two-rowed & $\begin{array}{l}\text { Lithuanian Institute of } \\
\text { Agriculture }\end{array}$ \\
\hline
\end{tabular}


Table 1 (continued)

\begin{tabular}{|c|c|c|c|c|c|c|c|}
\hline 1 & 2 & 3 & 4 & 5 & 6 & 7 & 8 \\
\hline 'Dotnuvos Ketureiliai' & AGB00256 & Lithuan ia & 1930 & cultivar & (S) local material & six-rowed & $\begin{array}{l}\text { Lithuanian Institute of } \\
\text { Agriculture }\end{array}$ \\
\hline 'Dziugiai' & AGB0257 & Lithuania & 1947 & cultivar & (S) local material & two-rowed & $\begin{array}{l}\text { Lithuanian Institute of } \\
\text { Agriculture }\end{array}$ \\
\hline 'Dainiai' & AGB00261 & Lithuania & 1981 & cultivar & '1561-12’ x 'Abed 3371' & two-rowed & $\begin{array}{l}\text { Lithuanian Institute of } \\
\text { Agriculture }\end{array}$ \\
\hline 'Vilnieciai' & AGB002263 & Lithuania & 1982 & cultivar & (M) 'Pallas' & two-rowed & $\begin{array}{l}\text { Lithuanian Institute of } \\
\text { Agriculture }\end{array}$ \\
\hline 'Gausiai' & AGB00255 & Lithuania & 1998 & cultivar & $\begin{array}{l}\text { 'Auksiniai II' x (MIX) } \\
\text { 'Viner'+'Bingo'+'Abed' +Archer' }\end{array}$ & two-rowed & $\begin{array}{l}\text { Lithuanian Institute of } \\
\text { Agriculture }\end{array}$ \\
\hline 'Aidas' & AGB00264 & Lithuania & 1990 & cultivar & ('KM 1192' x Ofir) x 'Effendi' & two-rowed & $\begin{array}{l}\text { Lithuanian Institute of } \\
\text { Agriculture }\end{array}$ \\
\hline 'Ūla' & AGB002265 & Lithuania & 1992 & cultivar & 'Roland' x 'Ca 33787' & two-rowed & $\begin{array}{l}\text { Lithuanian Institute of } \\
\text { Agriculture }\end{array}$ \\
\hline 'Alsa' & AGB002266 & Lithuania & 1993 & cultivar & $\begin{array}{l}\text { ('Minera’ x (M) ‘Gintariniai') x } \\
\text { (Abava x Emir) }\end{array}$ & two-rowed & $\begin{array}{l}\text { Lithuanian Institute of } \\
\text { Agriculture }\end{array}$ \\
\hline 'Aura' & AGB00267 & Lithuania & 1996 & cultivar & $\begin{array}{l}\text { ('Mirena' x (M)'Gintariniai) x } \\
\text { 'Lina' }\end{array}$ & two-rowed & $\begin{array}{l}\text { Lithuanian Institute of } \\
\text { Agriculture }\end{array}$ \\
\hline 'LIA 6107-26' & AGB00541 & Lithuania & - & breeding line & 'Roland' x 'Ca 53102' & two-rowed & $\begin{array}{l}\text { Lithuanian Institute of } \\
\text { Agriculture }\end{array}$ \\
\hline 'LIA 6700-28' & AGB00544 & Lithuania & - & breeding line & $\begin{array}{l}\text { 'Vega' x (Sv } 73608 \text { x WW 6405) x } \\
\text { 'HVS 929/77 x ('Chellas' x } \\
\text { 'Mirena') }\end{array}$ & two-rowed & $\begin{array}{l}\text { Lithuanian Institute of } \\
\text { Agriculture }\end{array}$ \\
\hline 'Luokè' & AGB00268 & Lithuania & 2001 & cultivar & $\begin{array}{l}\text { 'Vega' x ('Ofir' x 'Berenice) x } \\
\text { 'Flare' }\end{array}$ & two-rowed & $\begin{array}{l}\text { Lithuanian Institute of } \\
\text { Agriculture }\end{array}$ \\
\hline 'LIA 6804-62' & AGB00545 & Lithuania & - & breeding line & 'Ūla' x 'Korru' & two-rowed & $\begin{array}{l}\text { Lithuanian Institute of } \\
\text { Agriculture }\end{array}$ \\
\hline 'LIA 6121-02' & AGB00543 & Lithuania & - & breeding line & \multicolumn{2}{|c|}{$\begin{array}{l}\text { 'Krinichnij' x ('KM 1192' x 'Ofir') two-rowed } \\
\text { x'Deba' x 'KM 1192') }\end{array}$} & $\begin{array}{l}\text { Lithuanian Institute of } \\
\text { Agriculture }\end{array}$ \\
\hline 'LIA 6186-03-01' & AGB00542 & Lithuania & - & breeding line & \multicolumn{2}{|c|}{$\begin{array}{l}\text { ('KM } 1192 \text { ' x 'Ofir') x ('KM 1192'two-rowed } \\
\text { x 'Mami') x ('KM 1192' x 'Ofir') x } \\
\text { ('Maris Mink' x 'Nadia') }\end{array}$} & $\begin{array}{l}\text { Lithuanian Institute of } \\
\text { Agriculture }\end{array}$ \\
\hline
\end{tabular}

companies (Jõgeva Plant Breeding Institute, Priekuḷi and Stende Plant Breeding Stations in Latvia and Lithuanian Institute of Agriculture in Lithuania). Both six-rowed (7 accessions) and two-rowed (57 accessions) types were included in this study.

Isozyme analysis. Fresh leaves of one-week-old plants were harvested for the isozyme analysis. Ten individual plants per accession were examined. The methods for isozyme electrophoresis, staining and nomenclature were used as in Kolodinska Brantestam et al. (2003). Three isozyme systems (aconitase, esterase and phosphogluconate) for detecting polymorphism were employed for genetic profiling of the spring barley material. Eight isozyme loci where characterised. The designation of alleles at the Aco-1 and Pgd-2 loci followed that of Nielsen and Johansen (1986), at Est-1; Est-2, Est-4 and Est-5 loci Hvid followed Nielsen (1977) and at Aco-2 locus - Liu et al. (1999).

Microsatellite analysis. Fresh leaves of two-week-old plants were harvested for microsatellite analysis. Depending on the breeding period each accession was represented by a different number of examined individuals: eight individuals were selected for landraces and cultivars released until 1950 , and four individuals for the rest of material with the exception of breeding lines in which only two individuals were assessed. The methods of Kolodinska Brantestam et al. (2007) were used for DNA extraction, PCR reaction and fragment visualisation and 21 microsatellite primer pairs were used: Bmac0399, Bmac0032, WMC1E8, HVM36, Bmag0125, EBmac0415, HvLTPBB, Bmac0067, Bmac0067, Bmac0013, Bmac0384, EBmac0701, HVM67, EBmac0970, Bmac0223, AF043094, Bmag0173, EBmac0806, Bmac0040, Bmac0007, Bmac0273, Bmag0135. Twenty-two loci in total were characterised, as HvLPBB amplified fragments occurred at two sites. 
Statistical analysis. Gene diversity at each locus was calculated using the gene diversity index of Nei (1973). Total genetic diversity for the groups of accessions $\left(\mathrm{H}_{\mathrm{T}}\right)$ was estimated according to Hamrick and Godt (1997). Genetic distances (Rogers, 1972) between the accessions were calculated using the NTSYS-pc statistical package (Rolf, 1998). The analysis of molecular variance was performed using ARLEQUIN 3.1 software (Excoffier et al., 2005).

\section{RESULTS}

Marker diversity. For the three isozyme systems a total number of eight loci were analysed. Of these loci two were monomorphic and in six loci polymorphism was detected.
In total 15 alleles were found ( 1 to 3 alleles per locus) and the average genetic diversity $\left(\mathrm{H}_{\mathrm{T}}\right)$ was 0.244 (gene diversity $\mathrm{h}$ varied from 0 to 0.390 depending on the locus). Of the 22 microsatellite loci, all were polymorphic and in total 141 alleles ( 2 to 14 alleles per locus) were distinguished. The average genetic diversity based on microsatellite markers $\left(\mathrm{H}_{\mathrm{T}}\right)$ was 0.561 (gene diversity $\mathrm{h}$ varied from 0.031 to $0.858 \mathrm{de}$ pending on the locus) (Table 2).

Genetic profile and within accession variation. Individual genetic profiles at each isozyme and microsatellite locus for each accession are available in the complementary material of this paper (Appendix 1 and Appendix 2). Isozyme data showed that 34 accessions did not have within accession variation, whereas SSR data detected variation at one or

Table 2

ISOZYME AND MICROSATELLITE MARKER DIVERSITY

\begin{tabular}{|c|c|c|c|c|}
\hline Marker type & Loci & Alleles detected* & Number of alleles & Gene diversity (h) \\
\hline \multirow[t]{7}{*}{ Isozymes } & Aco-1 & $\mathrm{Ge}, \mathrm{Fn}$ & 2 & 0.34 \\
\hline & Aco-2 & A, B & 2 & 0.08 \\
\hline & Est-2 & $\mathrm{Fr}$ & 1 & 0 \\
\hline & Est-4 & $\mathrm{At}, \mathrm{Su}$ & 2 & 0.5 \\
\hline & Est-5 & $\mathrm{Pi}, \mathrm{Te}$ & 2 & 0.17 \\
\hline & Pdg-1 & $\mathrm{Ak}$ & 1 & 0 \\
\hline & Pdg-2 & Ps, Tn & 2 & 0.47 \\
\hline
\end{tabular}

Average values for isozyme loci

$\begin{array}{ll}\text { Bmac0399 } & 123,126,134,136,138,145,147 \\ \text { Bmac0032 } & 212,214,216,218,220,224,240 \\ \text { WMC1E8 } & 190,236 \\ \text { HVM36 } & 106,108,110,114,119 \\ \text { Bmag0125 } & 133,135,137,139,143,145 \\ \text { EBmac0415 } & 224,235,241,245,250 \\ \text { HvLTPBBa } & 218,220 \\ \text { HvLTPBBb } & 207,211 \\ \text { Bmac0067 } & 167,169,171,173,175,177,179,181,183 \\ \text { Bmac0013 } & 150,152,154,156,158,162,165 \\ \text { Bmac 0384 } & 112,114,116,118 \\ \text { EBmac } 0701 & 138,140,142,144,146,148,150,152,160 \\ \text { HVM67 } & 110,114,116,120 \\ \text { EBmac0970 } & 188,190,192 \\ \text { Bmac0223 } & 157,159,161,163,165,167,169,171,173,175,177,179,181,187 \\ \text { AF043094 A } & 145,146,147 \\ \text { Bmag0173 } & 121,123,126,130,142,144,146,148,150,152,0 * * \\ \text { EBmac0806 } & 162,164,170 \\ \text { Bmac 0040 } & 182,198,202,204,210,216,221,225,227,229,231,233,235,239 \\ \text { Bmac0007 } & 186,190,192,194,196,198,200,202,204,224 \\ \text { Bmac0273 } & 177,179,183,185,187,189 \\ \text { Bmag0135 } & 120,144,146,148,150,160,162,164 \\ & \end{array}$

* for isozymes allele names follow the references in which these alleles were designated (see methods), for microsatellites alleles are determined as fragment sizes in bp.

** 'zero allele', primer pairs did not amplify fragment at this loci 


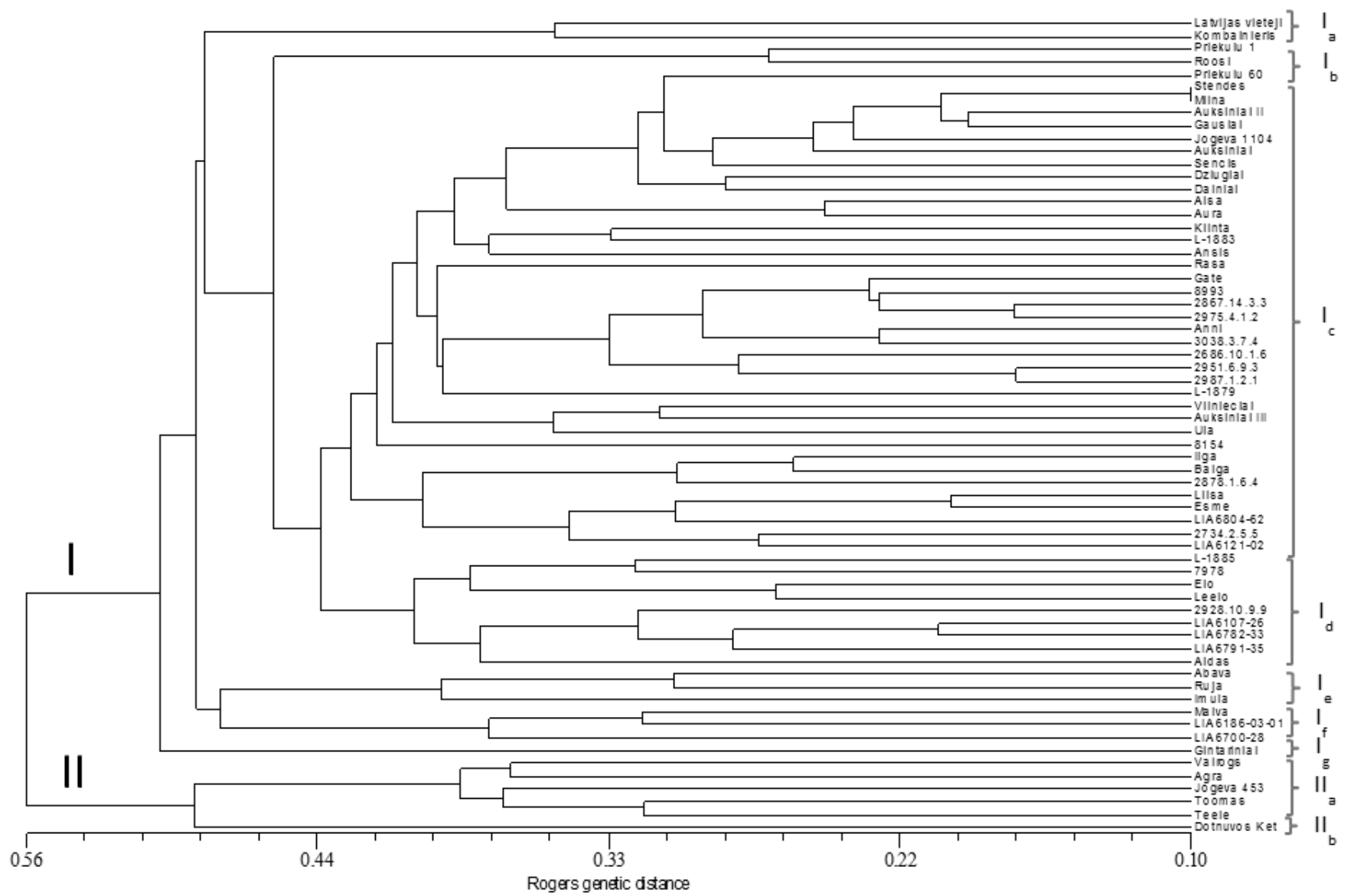

Fig. 1. Dendrogram based on pooled isozyme and microsatellite data demonstrating relationships between Baltic spring barley accessions.

more loci for all accessions analysed, with the exception of Estonian breeding line '2686.10.1.6' and Lithuanian cultivar 'Aura'. Based on isozyme data, 30 of the accessions could be distinguished by individual patterns of alleles and allele frequency distribution, whereas the remaining accessions formed groups from two to eight accessions which could not be separated. However, all of the accessions were distinguished by microsatellite data.

Genetic relationships. The dendrogram based on pooled isozyme and microsatellite data clearly separated material in two distant groups (I \& II) of accessions (Fig. 1). One included exclusively only six rowed accessions (II), whereas the other contained all of the two rowed accessions, with the exception of the 'Priekulu 1' cultivar that had a a six-rowed spike (I). The group of six-rowed material was further divided into two sub groups $\left(\mathrm{II}_{\mathrm{a}} \& \mathrm{II}_{\mathrm{b}}\right)$, where 'Dotnuvos Ketureiliai' $\left(\mathrm{II}_{\mathrm{b}}\right)$ appeared to be distant from the other six-rowed accessions in $\mathrm{II}_{\mathrm{a}}$. The predominantly two-rowed group of accessions (I) was divided into seven subgroups: subgroup $I_{a}$ containing landrace 'Latvijas vietējie' and cultivar 'Kombainieris', $I_{b}$ included two-rowed cultivars 'Roosi' and 'Priekulu 60'; $\mathrm{I}_{\mathrm{d}}$ - Estonian and Lithuanian breeding lines 'L1885', '7978', '2928.10.9.9', LIA-6107-26, 'LIA6782-33', 'LIA6791-35' and cultivars released after 1989 'Elo', 'Leelo' and 'Aidas'; I - Latvian cultivars 'Abava, Rūja' and 'Imula'; $I_{f}$ - Latvian cultivar 'Malva' and Lithuanian breeding lines 'LIA6186-03-01' and 'LIA670028'; $I_{c}$ included the remaining two-rowed accessions with the exception of cultivar 'Gintariniai', which fell into the seventh group $-I_{g}$.

Genetic diversity. When material from each country was analysed separately, the highest values for number of alleles and average gene diversity for SSR data were found for accessions released in the period between 1981 and 2000 (Table 3). For isozyme data, a similar pattern was observed. In Lithuanian accessions the total number of alleles was 12 for all periods, not including cultivars released from 1951 to 1980 in which this value was 10 , but the $\mathrm{H}_{\mathrm{T}}$ value was highest in accessions released from 1981 to 2000 , following the same trend as in Latvian and Estonian material (Table 3). When diversity was compared between accessions with different country of origin, the most diverse accessions according to isozyme data was material from Latvia $\left(\mathrm{H}_{\mathrm{T}}=0.27\right.$, $A=15)$, followed by material from Lithuania $\left(\mathrm{H}_{\mathrm{T}}=0.24\right.$, $\mathrm{A}=14)$. The Estonian material had the least diversity $\left(\mathrm{H}_{\mathrm{T}}=\right.$ $0.14, \mathrm{~A}=14)$. Microsatellite data showed also that Latvian accessions were most diverse $\left(\mathrm{H}_{\mathrm{T}}=0.56, \mathrm{~A}=114\right)$, followed by material from Lithuania $\left(\mathrm{H}_{\mathrm{T}}=0.53, \mathrm{~A}=109\right)$ and Estonia $\left(\mathrm{H}_{\mathrm{T}}=0.52, \mathrm{~A}=96\right)$. 
DIVERSITY OF ACCESSIONS IN DIFFERENT TYPES OF MATERIAL AND COUNTRY OF ORIGIN

\begin{tabular}{|c|c|c|c|c|c|}
\hline \multirow[b]{2}{*}{ Country } & \multirow[b]{2}{*}{ Type of material } & \multicolumn{2}{|c|}{ SSR } & \multicolumn{2}{|c|}{ Isozyme } \\
\hline & & $\begin{array}{c}\text { number of } \\
\text { alleles }\end{array}$ & $\begin{array}{c}\text { HT } \\
\text { (average gene } \\
\text { diversity) }\end{array}$ & $\begin{array}{c}\text { number of } \\
\text { alleles }\end{array}$ & $\begin{array}{c}\text { HT } \\
\text { (average gene } \\
\text { diversity) }\end{array}$ \\
\hline \multirow[t]{3}{*}{ Latvia } & Landraces and cultivars before 1950 & 49 & 0.41 & 13 & 0.28 \\
\hline & Cultivars 1951-1980 & 53 & 0.39 & 13 & 0.28 \\
\hline & Cultivars 1981-2000 & 92 & 0.53 & 15 & 0.28 \\
\hline \multirow[t]{4}{*}{ Estonia } & Landraces and cultivars before 1950 & 42 & 0.27 & 8 & 0 \\
\hline & Cultivars 1951-1980 & 55 & 0.42 & 12 & 0.24 \\
\hline & Cultivars 1981-2000 & 71 & 0.51 & 13 & 0.11 \\
\hline & Cultivars after 2001 and breeding lines & 63 & 0.40 & 11 & 0.08 \\
\hline \multirow[t]{4}{*}{ Lithuania } & Landraces and cultivars before 1950 & 73 & 0.44 & 12 & 0.15 \\
\hline & Cultivars 1951-1980 & 27 & 0.08 & 10 & 0.06 \\
\hline & Cultivars 1981-2000 & 71 & 0.47 & 12 & 0.21 \\
\hline & Cultivars after 2001 and breeding lines & 62 & 0.46 & 12 & 0.15 \\
\hline \multirow[t]{4}{*}{ All Baltic } & Landraces and cultivars before 1950 & 93 & 0.55 & 14 & 0.27 \\
\hline & Cultivars 1951-1980 & 82 & 0.50 & 13 & 0.29 \\
\hline & Cultivars 1981-2000 & 110 & 0.55 & 15 & 0.24 \\
\hline & Cultivars after 2001 and breeding lines & 93 & 0.51 & 12 & 0.18 \\
\hline
\end{tabular}

\section{DISCUSSION}

Genetic diversity. The distribution of molecular variation in Baltic spring barley demonstrated variation not only among but also within the accessions (Table $4 \mathrm{a}$ and $4 \mathrm{~b}$ ). The variation within accessions was significant when examined both by microsatellite and isozyme data and accounted for $20.6 \%$ or $14.3 \%$, respectively, of the total variation. This is an important fact to consider not only when developing management strategies for conservation in gene banks, but also when characterizing/evaluating these accessions and utilising them in research and breeding.

Several studies have reported changes in diversity due to plant breeding. These have shown different conclusions de-

Table 4

DISTRIBUTION OF VARIATION AMONG AND WITHIN ACCESSIONS

a

\begin{tabular}{c|c|c|c|c}
\multicolumn{5}{c}{ AMOVA based on isozyme data } \\
\hline Source of variation & d.f. & $\begin{array}{c}\text { Sum of } \\
\text { squares }\end{array}$ & $\begin{array}{c}\text { Variance } \\
\text { components }\end{array}$ & $\begin{array}{c}\text { Percentage } \\
\text { of variation }\end{array}$ \\
\hline Among accessions & 63 & 988.974 & $0.8669^{*}$ & 85.68 \\
Within accessions & 1086 & 157.343 & $0.1449^{*}$ & 14.32 \\
$\quad$ Total & 1149 & 1146.317 & 1.0118 &
\end{tabular}

b

\begin{tabular}{l|c|c|c|c}
\multicolumn{5}{c}{ AMOVA based on microsatellite data } \\
\hline Source of variation & d.f. & $\begin{array}{c}\text { Sum of } \\
\text { squares }\end{array}$ & $\begin{array}{c}\text { Variance } \\
\text { components }\end{array}$ & $\begin{array}{c}\text { Percentage } \\
\text { of variation }\end{array}$ \\
\hline Among accessions & 63 & 1802.138 & $4.1709 *$ & 79.37 \\
Within accessions & 360 & 390.312 & $1.084 *$ & 20.63 \\
Total & 423 & 2192.450 & 5.2551 &
\end{tabular}

$* P<0.000001$ pending on the country of origin of material, and have detected either temporal flux without genetic erosion, or somewhat lower diversity in modern material (Russel et al., 2000; Matus and Hayes, 2002; Koebner et al., 2003; Reeves et al., 2004; Kolodinska Brantestam et al., 2007). A meta study of diversity trends in released crop varieties in the twentieth century for eight different field crops (Wouw et al., 2010) concluded that significant decrease of diversity could not be detected. In our study groups of accessions from early breeding periods were unfortunately underrepresented, since there was only a limited set available in the gene banks. Thus, even though the highest diversity values were detected in cultivars released from 1981 to 2000, it cannot be safely concluded that this material is more diverse than material grown in the Baltic States in the early $20^{\text {th }}$ century. The few accessions representing landraces 'Latvijas vietējie' and early cultivars based on selection from local material, like 'Vairogs', 'Toomas', Dotnuvos Ketureililai' and 'Dziugiai' also demonstrated rather large genetic distances among them and were distributed in different clusters and sub-clusters in the dendrogram, with the exception of 'Vairogs' and 'Toomas' in sub-cluster $\mathrm{II}_{\mathrm{a}}$ (Fig. 1).

The higher diversity values in Latvian barley material compared to the other Baltic countries might be due to the history of breeding. Since the early $20^{\text {th }}$ century, two breeding companies have been actively working with cereal breeding. Some cereal breeding has also been performed at the Agricultural University of Latvia. The existence of several entities involved in breeding might have contributed to the diversity of the existing cultivars in Latvia, since different breeding strategies may have been employed and different material was used in crosses. 
Differentiation of accessions. The differentiation between two-and six rowed accessions based on molecular markers has been reported both in cultivars and landraces of barley from different countries of origin (Lasa and Igartua, 2001; Chaabane et al., 2009; Chen et al., 2009). The differentiation of two-rowed and six-rowed accessions was apparent also in Baltic barley material (Fig. 1) Also the AMOVA showed a significant share of variation that was explained by differentiation of two-rowed and six-rowed accessions (microsatellite data $16.95 \%, P<0.001$, isozyme data $26.84 \%, P<0.001)$. There were some differences in grouping of six-rowed versus two rowed accessions based on isozyme and microsatellite data. When only microsatellite data were used the two-rowed Latvian cultivar 'Imula' grouped together with the six-rowed accessions (data not shown). On the other hand, when data of microsatellite and isozyme were pooled, 'Imula' grouped together with the other two-rowed accessions (Fig. 1). This inconsistency might be because the accession has six-rowed Finnish and Norwegian material in the pedigree and thus depending on the DNA regions analysed, either similarity to two-rowed or six-rowed accessions can be detected.

Closer genetic relations between the accessions can be explained by common material used in the pedigrees. For example, the cultivar 'Abava' is found both in the pedigree of cultivar 'Imula' and 'Rūja' and these three cultivars are found in the same cluster $\mathrm{I}_{\mathrm{e}}$. However, 'Abava' is also present in the pedigree of Estonian cultivar 'Roosi' and Lithuanian cultivar 'Alsa', which are genetically rather distant and were found in different clusters $\mathrm{I}_{\mathrm{b}}$ and $\mathrm{I}_{\mathrm{c}}$, respectively.

There was no clear grouping of accessions according to the country of origin (Fig. 1). AMOVA analysis based on microsatellite data showed that the variation explaining differentiation among countries was not significant. The isozyme data, however, showed some variation $(9 \%, P=$ $0.001)$ that explained differences between countries. The weak differentiation of accessions by country of origin can be explained by common ancestors that were used in the breeding programmes in the Baltic countries. For example, on the basis of ancestral trees of Baltic barley, often common foreign material can be found, like 'Gull' from Sweden, 'Binder' and 'Hanna' from Moravia and 'Ackerman's Bavaria' from Bavaria. A more recent example is line 'KM 1192', which has been used by breeders in all three countries, and thereby can explain the location of Estonian breeding line '28781.6.4' and Latvian cultivars 'Ilga' and 'Balga' in the same sub cluster of $\mathrm{I}_{\mathrm{c}}$ (Fig. 1). Line 'KM 1192 ' predominantly was used as a powdery mildew resistance source (Tueryapijna et al., 1996) and other accessions (breeding line 'L1183', 'LIA612102', 'Aidas' and 'LIA6186-03-01') containing this line were not clustered together with 'Ilga', 'Balga' and '28781.6.4', which might be due to backcrossing with other material. It should also be noted that 'Ilga' and 'Balga' have the 'ulu2' gene from 'KM 1192', which it is not present in Lithuanian cultivar ‘Aidas' (Tueryapijna et al., 1996).

The isozyme variation represents variation of the coding region of the barley genome, whereas SSR in cereals predominantly represents the non-coding sequences (Kalia et al., 2011). This can explain why a limited set of isozymes explained greater variation due to the country of origin than was explained by microsatellite genetic variation. Even though many Baltic cultivars contain common material in their pedigree and are interrelated, there has been selection for traits separating Estonian, Latvian and Lithuanian material, in order to reach better agronomical performance for the target country.

\section{ACKNOWLEDGEMENTS}

We thank the Baltic breeding companies and gene banks for providing accessions included in this study. This study was part of the project "Genetic diversity in Nordic-Baltic crops - a model study of genetic erosion in barley" supported by the Royal Swedish Academy of Agriculture and Forestry.

Appendix 1

ALLELIC PROFILES OF ISOZYME LOCI FOR BALTIC BARLEY ACCESSIONS

\begin{tabular}{|c|c|c|c|c|c|c|c|c|}
\hline Accession & Aco-1 & Aco-2 & Est-1 & Est-2 & Est-4 & Est-5 & Pgd-1 & Pgd-2 \\
\hline 1 & 2 & 3 & 4 & 5 & 6 & 7 & 8 & 9 \\
\hline 'Latvijas vietējie' & $\mathrm{Ge}$ & B & $\mathrm{Ca} / \mathrm{Pr}$ & $\mathrm{Fr}$ & At & $\mathrm{Pi}$ & $\mathrm{Ak}$ & $\operatorname{Tn}$ \\
\hline 'Kombainieris' & Fn & B & $\mathrm{Ca} / \mathrm{Pr}$ & $\mathrm{Fr}$ & At & $\mathrm{Te}$ & $\mathrm{Ak}$ & Ps \\
\hline 'Priekuḷu 1' & Fn & B & $\operatorname{Pr}$ & Fr & $\mathrm{Su}$ & $\mathrm{Te}$ & $\mathrm{Ak}$ & $\operatorname{Tn}$ \\
\hline 'Priekuḷu 60' & $\mathrm{Ge}$ & B & $\mathrm{Ca}$ & $\mathrm{Fr}$ & At & $\mathrm{Pi}$ & $\mathrm{Ak}$ & Ps \\
\hline 'Stendes' & $\mathrm{Ge}$ & B & $\mathrm{Ca}$ & Fr & At & $\mathrm{Pi}$ & $\mathrm{Ak}$ & $\mathrm{Ps} / \mathrm{Tn}$ \\
\hline 'Abava' & $\mathrm{Ge}$ & B & $\operatorname{Pr}$ & $\mathrm{Fr}$ & $\mathrm{Su}$ & $\mathrm{Pi}$ & $\mathrm{Ak}$ & Ps \\
\hline 'Ilga' & $\mathrm{Ge}$ & B & $\mathrm{Al} / \mathrm{Ca}$ & $\mathrm{Fr}$ & At & $\mathrm{Te}$ & $\mathrm{Ak}$ & $\mathrm{Ps} / \mathrm{Tn}$ \\
\hline 'Agra' & $\mathrm{Ge}$ & $\mathrm{A} / \mathrm{B}$ & $\mathrm{Ca} / \mathrm{Pr}$ & Fr & $\mathrm{Su}$ & $\mathrm{Pi}$ & $\mathrm{Ak}$ & $\mathrm{Ps} / \mathrm{Tn}$ \\
\hline 'Imula' & Fn & B & $\operatorname{Pr}$ & $\mathrm{Fr}$ & $\mathrm{Su}$ & $\mathrm{Pi}$ & $\mathrm{Ak}$ & $\mathrm{Ps} / \mathrm{Tn}$ \\
\hline 'Balga' & $\mathrm{Ge}$ & B & $\mathrm{Ca}$ & $\mathrm{Fr}$ & At & $\mathrm{Pi}$ & $\mathrm{Ak}$ & $\operatorname{Tn}$ \\
\hline 'Klinta' & $\mathrm{Ge}$ & B & $\mathrm{Ca} / \mathrm{Pr}$ & $\mathrm{Fr}$ & $\mathrm{At} / \mathrm{Su}$ & $\mathrm{Pi}$ & $\mathrm{Ak}$ & Ps \\
\hline 'Rūja' & $\mathrm{Fn} / \mathrm{Ge}$ & B & $\operatorname{Pr}$ & $\mathrm{Fr}$ & $\mathrm{Su}$ & $\mathrm{Te}$ & $\mathrm{Ak}$ & Ps \\
\hline
\end{tabular}


Appendix 1 (continued)

\begin{tabular}{|c|c|c|c|c|c|c|c|c|}
\hline 1 & 2 & 3 & 4 & 5 & 6 & 7 & 8 & 9 \\
\hline 'Sencis' & $\mathrm{Ge}$ & $\mathrm{B}$ & $\mathrm{Ca} / \mathrm{Pr}$ & $\mathrm{Fr}$ & At & $\mathrm{Pi}$ & $\mathrm{Ak}$ & Ps/Tn \\
\hline 'Ansis' & $\mathrm{Ge}$ & B & $\mathrm{Ca}$ & $\mathrm{Fr}$ & $\mathrm{Su}$ & $\mathrm{Pi}$ & $\mathrm{Ak}$ & Ps \\
\hline 'Gate' & $\mathrm{Ge}$ & $\mathrm{B}$ & $\mathrm{Ca}$ & $\mathrm{Fr}$ & $\mathrm{Su}$ & $\mathrm{Pi}$ & $\mathrm{Ak}$ & $\operatorname{Tn}$ \\
\hline 'Malva' & Fn & B & $\operatorname{Pr}$ & $\mathrm{Fr}$ & $\mathrm{Su}$ & $\mathrm{Te}$ & $\mathrm{Ak}$ & Ps \\
\hline 'L-1879' & $\mathrm{Ge}$ & B & $\mathrm{Ca}$ & $\mathrm{Fr}$ & At & $\mathrm{Pi}$ & $\mathrm{Ak}$ & $\operatorname{Tn}$ \\
\hline 'L-1885' & $\mathrm{Ge} / \mathrm{Fn}$ & B & $\mathrm{Ca}$ & $\mathrm{Fr}$ & At & $\mathrm{Pi}$ & $\mathrm{Ak}$ & Tn \\
\hline '8154' & $\mathrm{Ge}$ & B & $\mathrm{Ca}$ & $\mathrm{Fr}$ & $\mathrm{Su}$ & $\mathrm{Pi}$ & $\mathrm{Ak}$ & Ps \\
\hline '7978' & $\mathrm{Ge}$ & B & $\mathrm{Ca}$ & $\mathrm{Fr}$ & At & $\mathrm{Pi}$ & $\mathrm{Ak}$ & $\operatorname{Tn}$ \\
\hline '8993' & $\mathrm{Ge}$ & B & $\mathrm{Ca}$ & $\mathrm{Fr}$ & $\mathrm{Su}$ & $\mathrm{Pi}$ & $\mathrm{Ak}$ & Ps \\
\hline 'Jogeva 453' & $\mathrm{Ge}$ & A & $\mathrm{Ca}$ & $\mathrm{Fr}$ & $\mathrm{Su}$ & $\mathrm{Pi}$ & $\mathrm{Ak}$ & $\operatorname{Tn}$ \\
\hline 'Jogeva 1104' & $\mathrm{Ge}$ & $\mathrm{B}$ & $\mathrm{Ca}$ & $\mathrm{Fr}$ & At & $\mathrm{Pi}$ & $\mathrm{Ak}$ & $\mathrm{Ps} / \mathrm{Tn}$ \\
\hline 'Liisa' & $\mathrm{Ge}$ & B & $\mathrm{Ca}$ & $\mathrm{Fr}$ & At & $\mathrm{Pi}$ & $\mathrm{Ak}$ & $\operatorname{Tn}$ \\
\hline 'Miina' & $\mathrm{Ge}$ & B & $\mathrm{Ca} / \mathrm{Pr}$ & $\mathrm{Fr}$ & At & $\mathrm{Pi}$ & $\mathrm{Ak}$ & $\mathrm{Ps} / \mathrm{Tn}$ \\
\hline 'Esme' & $\mathrm{Ge}$ & B & $\mathrm{Ca}$ & $\mathrm{Fr}$ & At & $\mathrm{Pi}$ & $\mathrm{Ak}$ & $\operatorname{Tn}$ \\
\hline 'Elo' & $\mathrm{Ge}$ & B & $\mathrm{Ca}$ & $\mathrm{Fr}$ & At & $\mathrm{Pi}$ & $\mathrm{Ak}$ & $\operatorname{Tn}$ \\
\hline 'Teele' & $\mathrm{Fn} / \mathrm{Ge}$ & $\mathrm{B}$ & $\operatorname{Pr}$ & $\mathrm{Fr}$ & $\mathrm{Su}$ & $\mathrm{Pi}$ & $\mathrm{Ak}$ & $\operatorname{Tn}$ \\
\hline 'Anni' & $\mathrm{Ge}$ & B & $\mathrm{Ca}$ & $\mathrm{Fr}$ & $\mathrm{Su}$ & $\mathrm{Pi}$ & $\mathrm{Ak}$ & $\operatorname{Tn}$ \\
\hline 'Leelo' & $\mathrm{Ge}$ & B & $\mathrm{Al} / \mathrm{Ca}$ & $\mathrm{Fr}$ & $\mathrm{At} / \mathrm{Su}$ & $\mathrm{Pi}$ & $\mathrm{Ak}$ & $\operatorname{Tn}$ \\
\hline 'Roosi' & $\mathrm{Ge}$ & $\mathrm{B}$ & $\mathrm{Ca}$ & $\mathrm{Fr}$ & $\mathrm{Su}$ & $\mathrm{Pi}$ & $\mathrm{Ak}$ & $\operatorname{Tn}$ \\
\hline '2686.10.1.6' & $\mathrm{Ge}$ & B & $\mathrm{Ca}$ & $\mathrm{Fr}$ & $\mathrm{Su}$ & $\mathrm{Pi}$ & $\mathrm{Ak}$ & $\operatorname{Tn}$ \\
\hline '2734.2.5.5' & $\mathrm{Ge}$ & $\mathrm{B}$ & $\mathrm{Ca}$ & $\mathrm{Fr}$ & At & $\mathrm{Pi}$ & $\mathrm{Ak}$ & $\operatorname{Tn}$ \\
\hline '2867.14.3.3' & $\mathrm{Ge}$ & B & $\mathrm{Ca}$ & $\mathrm{Fr}$ & $\mathrm{Su}$ & $\mathrm{Pi}$ & $\mathrm{Ak}$ & $\operatorname{Tn}$ \\
\hline '2878.1.6.4' & $\mathrm{Ge}$ & $\mathrm{B}$ & $\mathrm{Ca}$ & $\mathrm{Fr}$ & $\mathrm{Su}$ & $\mathrm{Pi}$ & $\mathrm{Ak}$ & $\operatorname{Tn}$ \\
\hline '2975.41.2' & $\mathrm{Ge}$ & $\mathrm{B}$ & $\operatorname{Pr}$ & $\mathrm{Fr}$ & $\mathrm{Su}$ & $\mathrm{Pi}$ & $\mathrm{Ak}$ & $\operatorname{Tn}$ \\
\hline '2987.1.2.1' & $\mathrm{Ge}$ & B & $\mathrm{Ca}$ & $\mathrm{Fr}$ & $\mathrm{At} / \mathrm{Su}$ & $\mathrm{Pi}$ & $\mathrm{Ak}$ & $\operatorname{Tn}$ \\
\hline '3038.37.4' & $\mathrm{Ge}$ & $\mathrm{B}$ & $\mathrm{Ca}$ & $\mathrm{Fr}$ & $\mathrm{Su}$ & $\mathrm{Pi}$ & $\mathrm{Ak}$ & $\operatorname{Tn}$ \\
\hline 'Auksiniai' & $\mathrm{Ge}$ & B & $\mathrm{Ca} / \mathrm{Pr}$ & $\mathrm{Fr}$ & At & $\mathrm{Pi}$ & $\mathrm{Ak}$ & $\mathrm{Ps} / \mathrm{Tn}$ \\
\hline 'Dotnuvos Ketureiliai' & $\mathrm{Ge}$ & $\mathrm{A} / \mathrm{B}$ & $\mathrm{Ca} / \mathrm{Pr}$ & $\mathrm{Fr}$ & At & $\mathrm{Pi}$ & $\mathrm{Ak}$ & Ps/Tn \\
\hline 'Auksiniai II' & $\mathrm{Ge}$ & $\mathrm{B}$ & $\mathrm{Ca} / \mathrm{Pr}$ & $\mathrm{Fr}$ & $\mathrm{At} / \mathrm{Su}$ & $\mathrm{Pi}$ & $\mathrm{Ak}$ & Ps \\
\hline 'Dziugiai' & $\mathrm{Ge}$ & $\mathrm{B}$ & $\mathrm{Ca}$ & $\mathrm{Fr}$ & $\mathrm{At} / \mathrm{Su}$ & $\mathrm{Pi}$ & $\mathrm{Ak}$ & Ps \\
\hline 'Gintariniai' & $\mathrm{Ge}$ & $\mathrm{B}$ & $\mathrm{Ca} / \mathrm{Pr}$ & $\mathrm{Fr}$ & At & $\mathrm{Te}$ & $\mathrm{Ak}$ & $\mathrm{Ps} / \mathrm{Tn}$ \\
\hline 'Dainai' & $\mathrm{Ge}$ & B & $\mathrm{Ca} / \mathrm{Pr}$ & $\mathrm{Fr}$ & At & $\mathrm{Pi}$ & $\mathrm{Ak}$ & $\mathrm{Ps} / \mathrm{Tn}$ \\
\hline 'Vilnieciai' & $\mathrm{Ge}$ & $\mathrm{B}$ & $\operatorname{Pr}$ & $\mathrm{Fr}$ & $\mathrm{Su}$ & $\mathrm{Pi}$ & $\mathrm{Ak}$ & Ps \\
\hline 'Gausai' & $\mathrm{Ge}$ & B & $\mathrm{Ca}$ & $\mathrm{Fr}$ & At & $\mathrm{Pi}$ & $\mathrm{Ak}$ & Ps \\
\hline 'Auksiniai 3' & $\mathrm{Ge}$ & B & $\operatorname{Pr}$ & $\mathrm{Fr}$ & $\mathrm{Su}$ & $\mathrm{Pi}$ & $\mathrm{Ak}$ & $\mathrm{Ps} / \mathrm{Tn}$ \\
\hline 'Aidas' & Fn & $\mathrm{B}$ & $\mathrm{Ca}$ & $\mathrm{Fr}$ & At & $\mathrm{Pi}$ & $\mathrm{Ak}$ & $\mathrm{Tn}$ \\
\hline 'Ula' & $\mathrm{Ge}$ & B & $\mathrm{Ca} / \mathrm{Pr}$ & $\mathrm{Fr}$ & $\mathrm{Su}$ & $\mathrm{Pi}$ & $\mathrm{Ak}$ & $\operatorname{Tn}$ \\
\hline 'Alsa' & $\mathrm{Fn} / \mathrm{Ge}$ & B & $\mathrm{Ca}$ & $\mathrm{Fr}$ & At & $\mathrm{Pi}$ & $\mathrm{Ak}$ & Ps/Tn \\
\hline 'Aura' & $\mathrm{Ge}$ & B & $\mathrm{Ca}$ & $\mathrm{Fr}$ & At & $\mathrm{Pi}$ & $\mathrm{Ak}$ & $\operatorname{Tn}$ \\
\hline '6107-26' & Fn & B & $\mathrm{Ca}$ & $\mathrm{Fr}$ & At & $\mathrm{Pi}$ & $\mathrm{Ak}$ & $\operatorname{Tn}$ \\
\hline '6700-28' & Fn & $\mathrm{B}$ & $\mathrm{Ca} / \mathrm{Pr}$ & $\mathrm{Fr}$ & $\mathrm{At} / \mathrm{Su}$ & $\mathrm{Pi}$ & $\mathrm{Ak}$ & $\mathrm{Ps} / \mathrm{Tn}$ \\
\hline '6782-33' & Fn & B & $\mathrm{Ca}$ & $\mathrm{Fr}$ & At & $\mathrm{Pi}$ & $\mathrm{Ak}$ & $\mathrm{Ps} / \mathrm{Tn}$ \\
\hline '6791-35' & $\mathrm{Fn} / \mathrm{Ge}$ & B & $\mathrm{Ca}$ & $\mathrm{Fr}$ & At & $\mathrm{Pi}$ & $\mathrm{Ak}$ & $\mathrm{Tn}$ \\
\hline '6804-62' & Fn & B & $\mathrm{Ca}$ & $\mathrm{Fr}$ & At & $\mathrm{Pi}$ & $\mathrm{Ak}$ & $\mathrm{Tn}$ \\
\hline '6121-02' & Fn & B & $\mathrm{Ca}$ & $\mathrm{Fr}$ & At & $\mathrm{Pi}$ & $\mathrm{Ak}$ & $\operatorname{Tn}$ \\
\hline '6186-03-01' & Fn & B & $\mathrm{Ca} / \mathrm{Pr}$ & $\mathrm{Fr}$ & $\mathrm{At} / \mathrm{Su}$ & $\mathrm{Pi}$ & $\mathrm{Ak}$ & $\mathrm{Ps} / \mathrm{Tn}$ \\
\hline
\end{tabular}




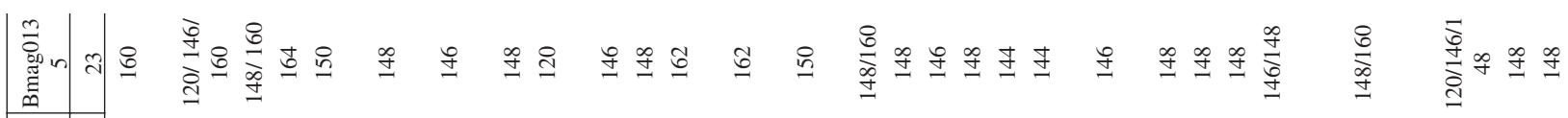

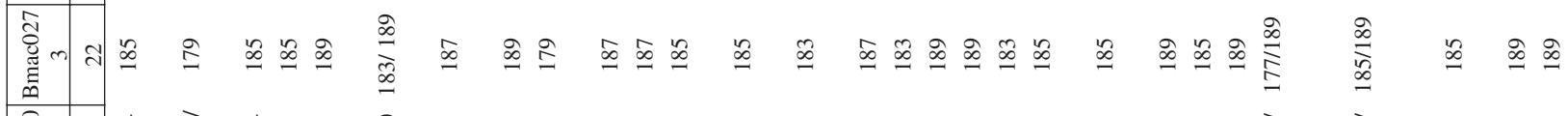

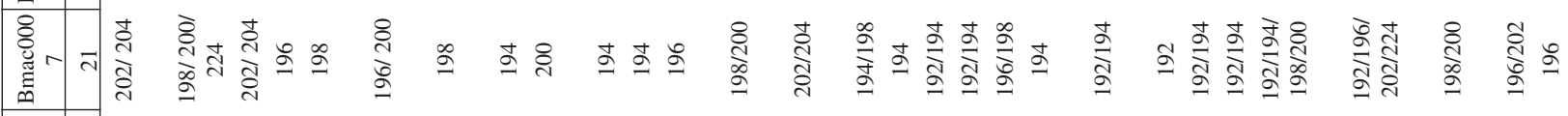

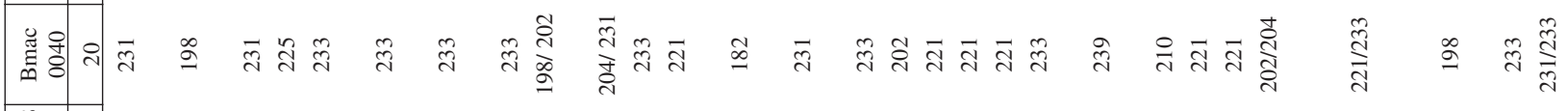

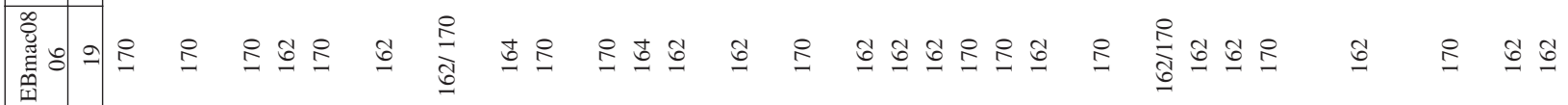

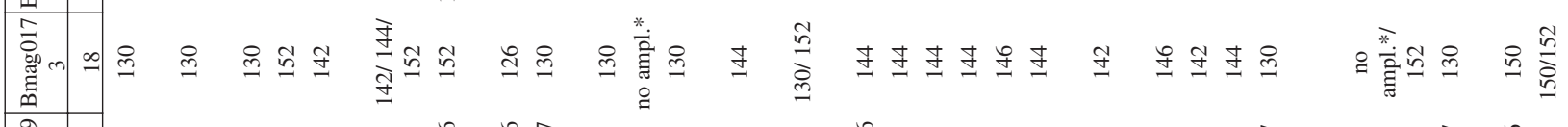

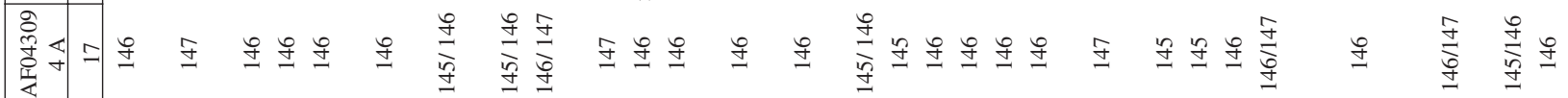

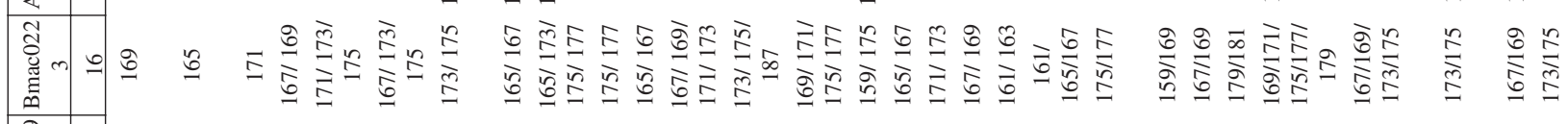

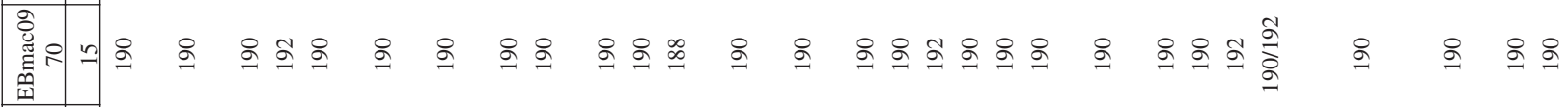

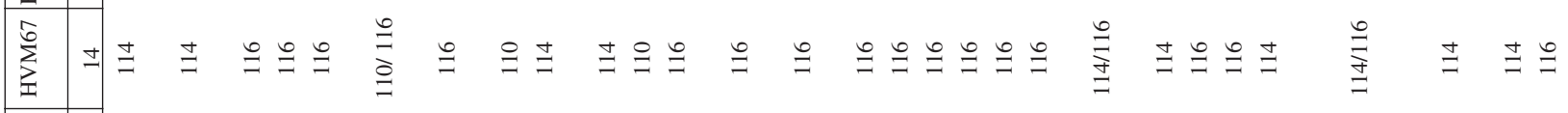

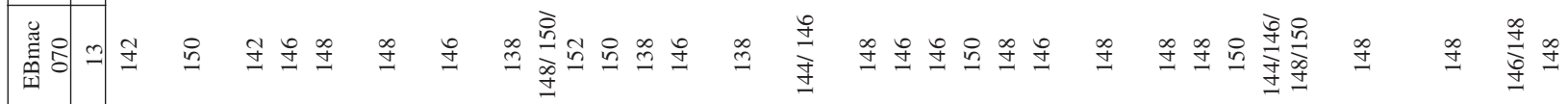

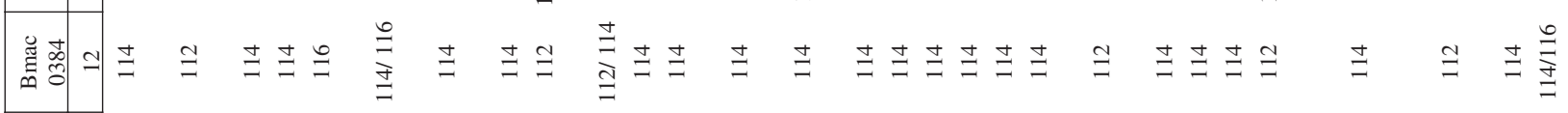

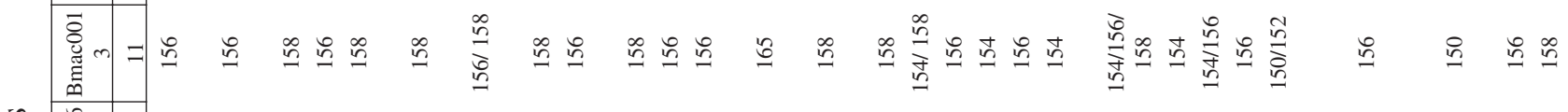

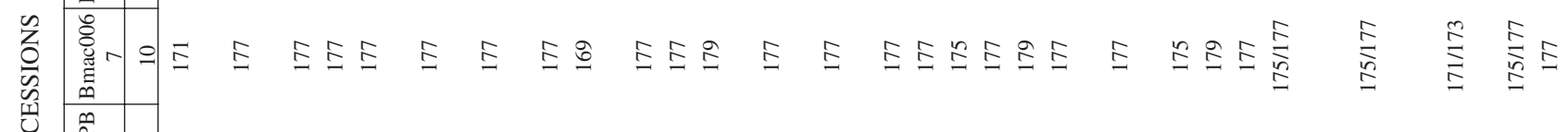

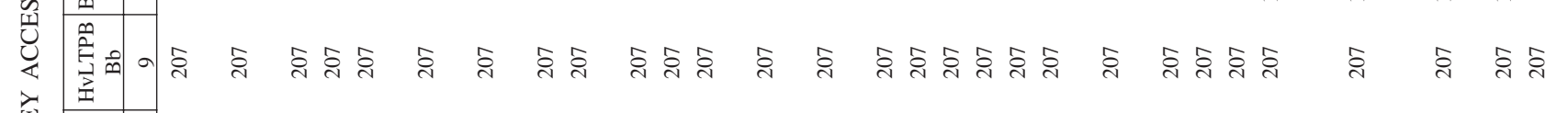

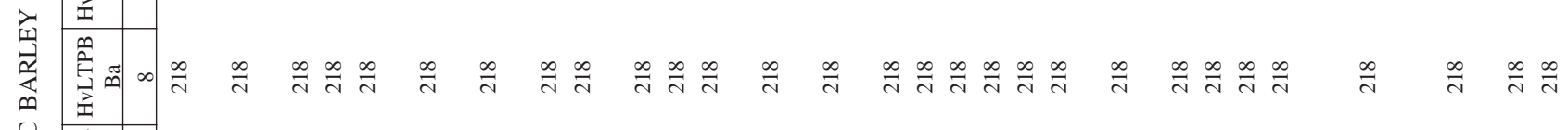

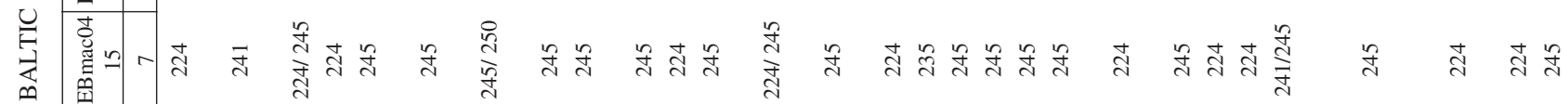

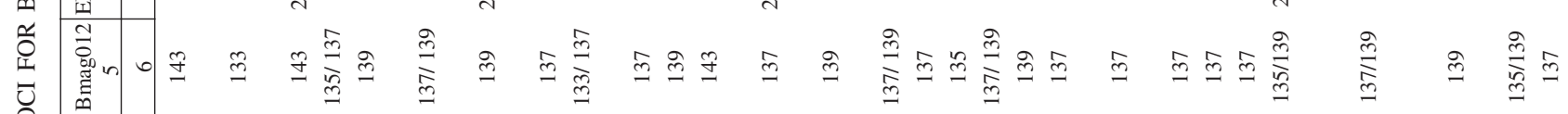

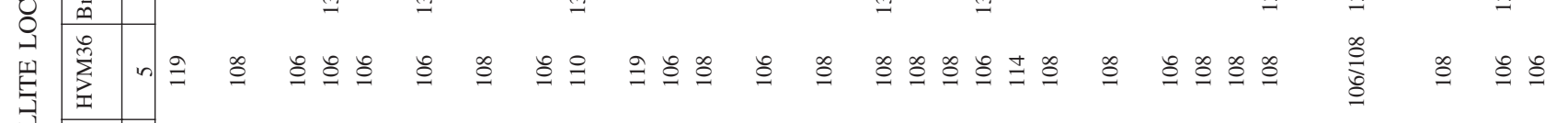

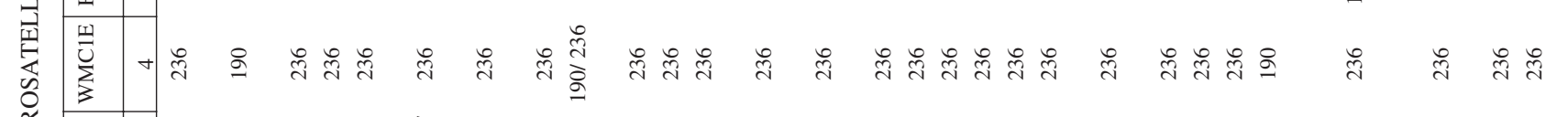

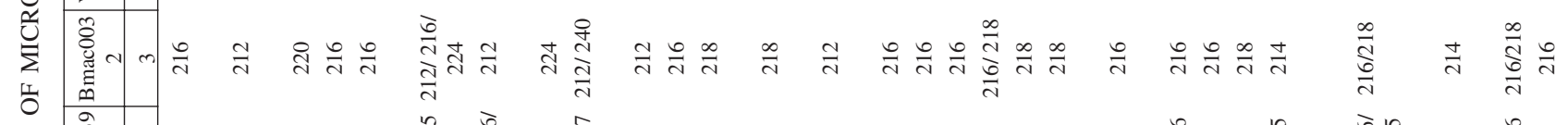

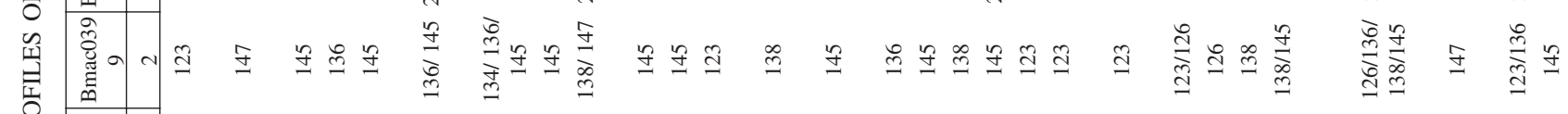

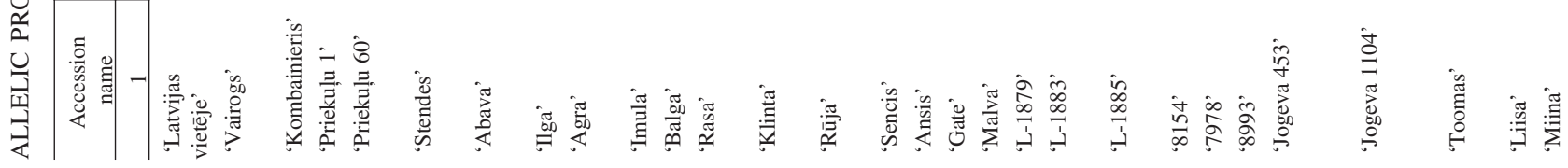




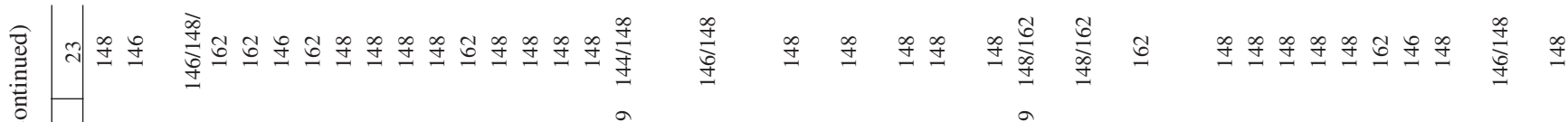

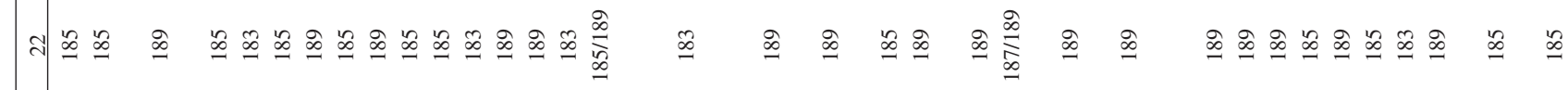

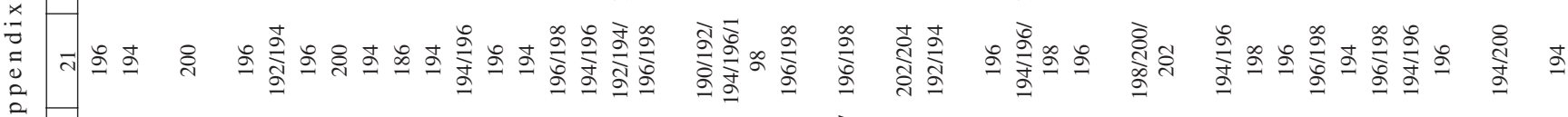
๙ -

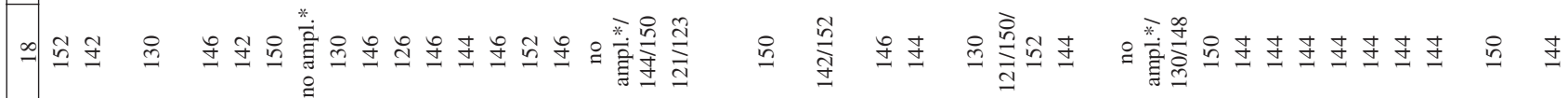

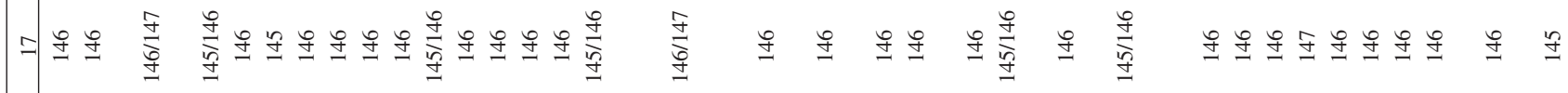

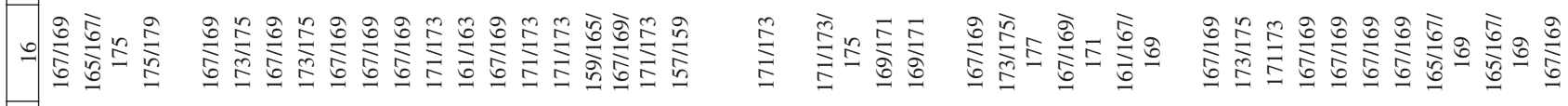

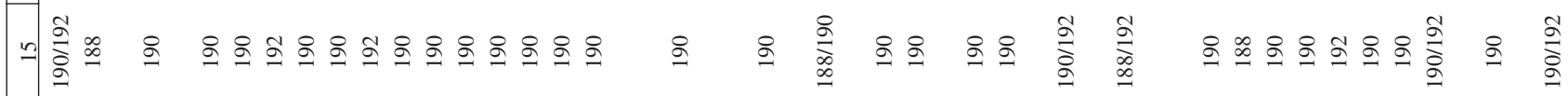

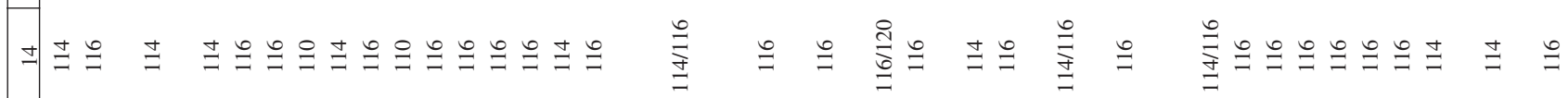

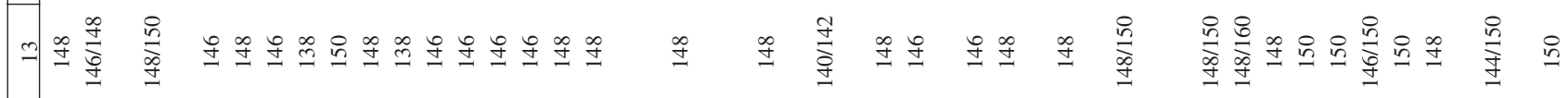

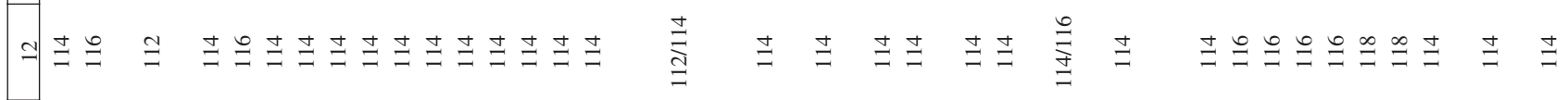

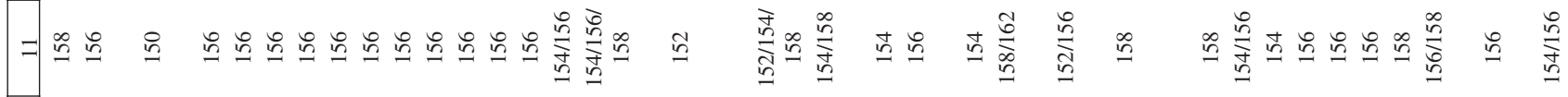
올

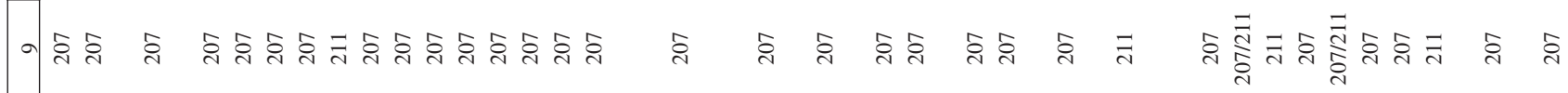

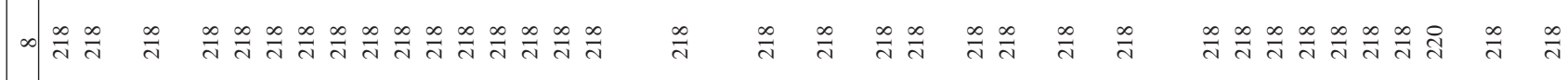

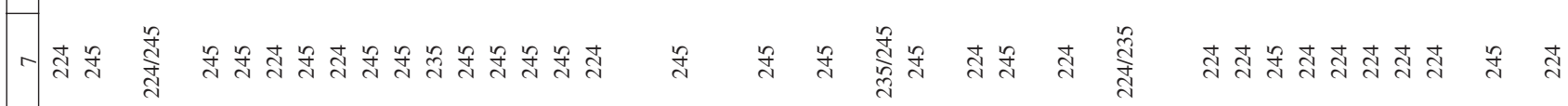

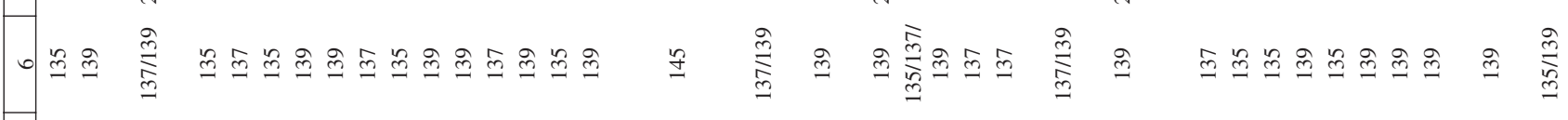

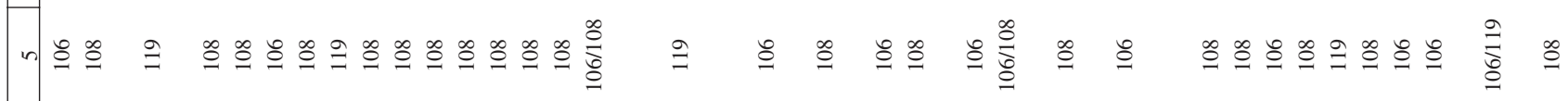
†

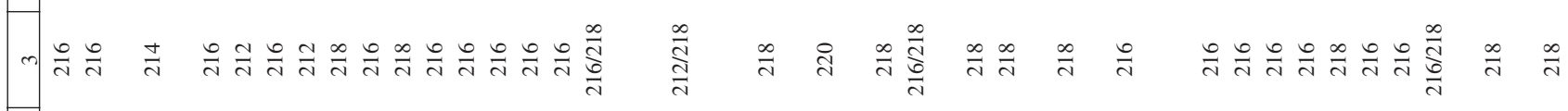

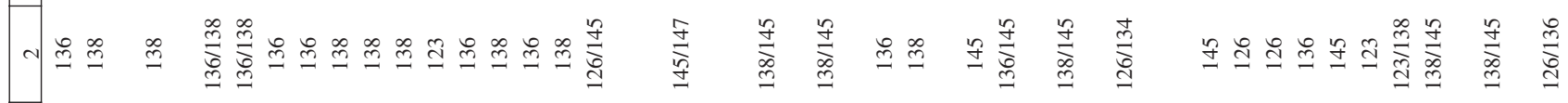

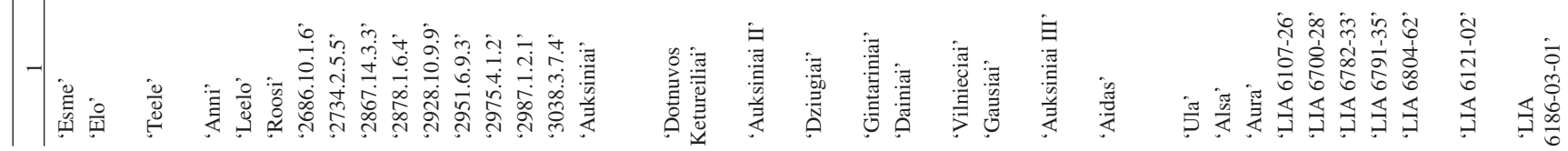




\section{REFERENCES}

Anonymous (2012). FAO. http://www.fao.org

Chaabane, R., Felah, M. E., Salah, H.B., Nauceur, M.B.B., Abdelly, C., Ramala, D., Nada, A., Saker, M. (2009). Molecular characterization of Tunisian barley (Hordeum vulgare L.) genotypes using microsatellites (SSRs) markers. Eur. J. Sci. Res., 36, 6-15.

Chen, F., Chen, D., Brau V., Pilar, M., Gao, Z., Chen, X. (2009). Analysis of diversity in Chinese cultivated barley with simple sequence repeats: Differences between eco-geographic populations. Biochem. Gen., 48, 44-56.

Excoffier, L., Laval, G., Schneider, S. (2005). Arlequin ver. 3.0: An integrated software package for population genetics data analysis. Evolutionary Bioinformatics Online, 1, 47-50.

Hamrick, J.L., Godt, M.J.W. (1997). Allozyme diversity in cultivated crops. Crop Sci., 37, 26-30.

Hvid, S., Nielsen, G. (1977). Esterase isoenzyme variants in barley. Hereditas, 87, 155-162.

Kalia, R.K., Manoj, K.-R., Kalia, S., Singh, R., Dhawan, A.K. (2011). Microsatellite markers: An overview of the recent progress in plants. Euphitica, 177, 309-334.

Koebner, R.M.D., Donini, P., Reeves, J.C., Cooke, R.J., Law, J.R. (2003). Temporal flux in the morphological and molecular diversity of UK barley. Theor. Appl. Gen., 106, 550-558.

Kolodinska Brantestam, A. (2005). A century of Breeding - is genetic erosion a reality? Temporal diversity changes in Nordic and Baltic barley. Doctoral thesis No. 2005:30. Swedish University of Agricultural Sciences.

Kolodinska Brantestam, A., von Bothmer R., Rashal, I., Weibull, J. (2003). Changes in the genetic diversity of barley of Nordic and Baltic origin, studied by isozyme electrophoresis. Plant Gen. Res.: Characterization and Utilization, 1, 143-149.

Kolodinska Brantestam A., von Bothmer R., Dayteg C., Rashal I., Tuvesson S., Weibull, J. (2007). Genetic diversity changes and relationships in spring barley (Hordeum vulgare L.) germplasm of Nordic and Baltic areas as shown by SSR markers. Gen. Res. Crop Evol., 54, 749-758.

Lasa, J., Igartua, E. (2001). Morphological and agronomical diversity patterns in the Spanish barley core collection. Hereditas, 135, 217-225.
Liu F., von Bothmer R., Salomon, B. (1999). Genetic diversity among East Asian accessions of the barley core collection as revealed by six isozyme loci. Theor. Appl., Gen., 98, 1226-1233.

Matus, I.A., Hayes, P.M. (2002). Genetic diversity in three groups of barley germplasm assessed by simple sequence repeats. Genome, 45, 1095-1106.

Nei, M. (1973). Analysis of gene diversity insubdivided populations. Proc. Nat. Acad. Sci. USA, 70, 3321-3323.

Nielsen G., Johansen, H. (1986). Proposal for identification of barley varieties based on the genotypes for 2 hordein and 39 isoenzyme loci of 47 reference varieties. Euphtica, 35, 717-728.

Reeves, J.C., Chiapparino, E., Donini, P., Ganal, M., Guiard, J., Hamrit, S., Heckenberger, M., Huang, X.-Q., van Kaauwen, M., Kochieva, E., Koebner, R., Law, J.R, Lea, V., Le Clerc, V., van der Lee, T., Leigh, F., van der Linden, G., Malysheva, L., Melchinger, A.E., Orford, S., Reif, J.C., Röder, M., Schulman A., Vosman, B., van der Wiel, C., Wolf, M., Zhang, D. (2004). Changes over time in the genetic diversity of four major European crops from the Gediflux Framework 5 project. In: Proceedings of $17^{\text {th }}$ EUCARPIA General Congress: Genetic variation for plant breeding (pp. 3-7). Vollmann, J., Grausgruber, H., Ruckenbauer, P. (eds.). Vienna: University of Natural Resources and Applied Life Sciences.

Rogers, J.S. (1972). Measures of genetic similarity and genetic distance. In Studies in Genetics. Vol. VII (pp. 145-153). Publ. 7213. Austin: University of Texas.

Rolf, M. (1998). NTSYS-pc: Numerical taxonomy and multivariate analysis system. Version 2.1. Department of Ecology and Evolution. New York: State University of New York.

Russel, J., Ellis, R., Thomas, B., Waugh, R., Provan, J., Booth, A., Fuller, J., Lawrence, P., Young, G., Powell, W. (2000). A retrospective analysis of spring barley germplasm development from 'foundation' genotypes' to currently successful cultivars. Mol. Breed., 6, 553-568.

Tueryapina, R., Jensen, H.P., Rashal, I. (1996). Powdery mildew resistance genes in Baltic spring barley varieties and breeding lines. Barley Gen. Newslett., 27, 18-21.

van de Wouw, M., van Hintum, T., Kik, C., van Treuren, R., Visser, B. (2010). Genetic diversity trends in twentieth century crop cultivars: A meta analysis. Theor. Appl. Gen., 120, 1241-1252.

Received 25 January 2012

\section{BALTIJAS VALSTU VASARAS MIEŽU ĢENĒTISKIE PROFILI UN DAUDZVEIDĪBA}

Šì darba mērḳis bija iegūt datus molekulārai pasportizācijai, ko var izmantot dažādu Baltijas izcelsmes vasaras miežu paraugu identifikācijai, kā arī novērtēt to ǵenētisko daudzveidību. Alēlu profili 21 mikrosatelītu un astoņos izoenzīmu lokusos tika noteikti 64 Baltijas vasaras miežu paraugiem. Pamatojoties uz mikrosatelītu alēlu sastāvu un frekvencēm, varēja izškirt visus analizētos paraugus. Attiecīgie izoenzīmu dati, turpretī, l̦āva izšḳirt tikai 30 no analizētajiem paraugiem. G̦enētiskā mainība starp indivīdiem paraugu robežā veidoja 20,6\% no kopējās mainības, balstoties uz mikrosatelītu datiem, un 14,3\% no kopējās mainības — pēc izoenzīmu datiem. Divkanšu un seškanšu miežus varēja skaidri izškirt, gan izmantojot mikrosatelītu, gan izoenzīmu markieru datus. Saskanā ar AMOVA analīzi ǵenētiskās mainības daḷa, kas noteica atškirību starp divkanšu un seškanšu materiālu, veidoja 16,9\% no kopējās mainības, pamatojaties uz mikrosatelītu datiem, un $26.8 \%$ - pamatojoties uz izoenzīmu datiem. Būtiska paraugu diferenciācija atkarībā no izcelsmes valsts tika konstatēta tikai attiecībā uz izoenzīmu datiem un veidoja 9\% no kopējās mainības. Gan izoenzīmu, gan mikrosatelītu dati parādīja, ka Latvijas izcelsmes paraugi ir ġenētiski daudzveidīgākie, bet Igaunijas paraugi — vienveidīgākie Baltijas vasaras miežu paraugu vidū. 